Boston University School of Law Scholarly Commons at Boston University School of Law

Spring 1990

\title{
Matrimonial Bonds: Slavery and Divorce in Nineteenth-Century America
}

Elizabeth B. Clark

Follow this and additional works at: https://scholarship.law.bu.edu/clark_pubs

Part of the Family Law Commons, and the Legal History Commons

\section{Recommended Citation}

Elizabeth B. Clark, Matrimonial Bonds: Slavery and Divorce in Nineteenth-Century America, 8 Law \& Hist. Rev. 25 (1990).

This Article is brought to you for free and open access by the Betsy Clark Living Archive at Scholarly Commons at Boston University School of Law. It has been accepted for inclusion in Publications by an authorized BOSTON administrator of Scholarly Commons at Boston University School of Law. For more information, please contact lawlessa@bu.edu. 


\title{
Matrimonial Bonds: Slavery and Divorce in Nineteenth-Century America
}

\author{
ELIZABETH B. CLARK
}

[I]n the covenant of marriage, [woman] is compelled to promise obedience to her husband, he becoming, to all intents and purposes, her master - the law giving him power to deprive her of her liberty, and to administer chastisement. He has so framed the law of divorce... as to be wholly regardless of the happiness of women - the law, in all cases, going upon a false supposition of the supremacy of man, and giving all power into his hands. ${ }^{1}$

As early as 1848 , in the first public meeting on woman's rights, feminists raised the touchy issues of women's marital subjugation and divorce. They complained that the laws of marriage and divorce were framed for the benefit of men and to entrap women within the oppressive institution of marriage. Another controversial claim made at Seneca Falls - that to the ballot - went on to become the great organizing principle for women's campaigns for legal and political reform. But despite the bold beginning, divorce remained a complex and divisive issue for feminists throughout the century. Although legislatures in most states in the mid-nineteenth century were systematically liberalizing divorce laws, they could not lift the social stigma attached to it. ${ }^{2}$ Fearful of being branded as anti-marriage or anti-family, or believing in the permanency of marriage, many feminists spoke of divorce reluctantly, and never used their formidable organizing skills to launch a full-scale assault on laws restricting the dissolution of marriage.

Elizabeth Cady Stanton stood as the great exception to this rule. An early and ardent champion of liberal divorce, her arguments were highly influential in the development of nineteenth-century feminist theory. ${ }^{3}$ A few feminists followed Stanton whole-heartedly, some agreed

Elizabeth B. Clark is assistant professor of law, University of Pennsylvania. 
with her in part, still others were shocked at her advocacy of measures they felt would tend toward the disruption of marriage and the family. Yet even for those feminists who resisted her conclusions, the analysis of marriage she offered- "from covenant to contract" could have been her rallying cry-was transformative. Despite its mixed reception, Stanton's theory of divorce and family relations helped to shape nineteenth-century American attitudes toward marriage.

Stanton's theory of divorce became as well a critical platform for her maturing theory of rights, which was far more in tune with both mainstream feminist and liberal thought of her day than were her ideas about divorce. Stanton's work, emphasizing the ultimate "right" to free oneself from obligations that had become unwanted bonds, paved the way for a liberal feminist theory that rested on the autonomy of the individual. She helped to promote both the growth of a family law based on a contractual theory of relations and a view of politics that deemed the rights of individuals paramount. In Stanton's work, personal autonomy began to constitute the individual's citizenship in a way that has become a dominant motif in American life.

Stanton's vision of individual rights drew heavily on ideas of slavery and freedom, and the debate over their definitions that raged in postCivil War America. Stanton's adoption of the radical extremes of freedom and slavery to describe the condition of women has left a mixed legacy. The most brilliant and dynamic feminist theorist of her day, she helped forge a language of individual liberty that acted as a catalyst for social change. ${ }^{4}$ Nevertheless, the adoption of the slavery paradigm to describe marriage narrowed Stanton's perceptions of women's condition and dictated an appeal to a specific sort of legal remedy that both shaped and limited feminist goals during the nineteenth century.

\section{Divorce in the Antebellum Era}

In January of 1853, Elizabeth Cady Stanton, acting on behalf of the New York State Woman's Temperance Society, offered a ten-dollar prize for the best essay entitled "The Duty of the Drunkard's Wife," in the women's temperance newspaper Lily. The readers of the Lily, themselves a progressive group, rose to the challenge. ${ }^{5}$ Well coached, all took the position that Stanton and Susan B. Anthony had been urging in the Lily's columns in the preceding months: that wives of chronic inebriates had a duty to seek a separation, to sever the conjugal relationship, so as not to be the agent of breeding a drunkard's children. 
The contestants, however, chose in the end to resolve their characters' problems through separation, death, or desertion; none broached the subject of legal divorce. Half-measures never satisfied Stanton, and for her these analyses fell short: The Lily contains no record of the prize being awarded.

The liberalization of divorce laws was by no means foreordained. Even progressive minds feared the path to easy divorce, disagreeing about its significance, its desirability, and its consequences. Antebellum reformers recognized the need for legal separation or divorce most consistently in the case of the chronically drunken husband. Under these circumstances, a virtually unanimous consensus prevailed that the law must somehow intervene. The Lily, whose subject matter ranged between the poles of temperance and women's rights, rendered in particularly lurid tones the plight of the battered mother bound for life to a "moral monster-[a] vulgar, gross, imbruted nature."' Indeed, feminists who remained deeply committed to the Christian ideal of lifelong marriage agreed on the need for the equivalent of a legal separation, contingent upon reforms in the law of marital property to safeguard women's rights.

Fueled by the broader reform agitation over family law in the 1850 s, the debate on divorce extended beyond feminist circles. In the early $1850 \mathrm{~s}$, the editor of the New York Tribune, Horace Greeley, engaged the anarchist and free lover Stephen Pearl Andrews and the Boston Swedenborgian Henry James, Sr., in an extended and highly publicized debate over the ongoing liberalization of divorce laws. In 1860, Greeley took up his cudgel again, this time against Robert Dale Owen, son of communitarian Robert Owen. ${ }^{7}$ Not just divorce but the function of family law was at stake in these debates. Greeley served as the linchpin, or perhaps the lightning rod, articulating a strain of thought that held that family law existed to coerce "moral" or socially desirable behavior. He valued the maintenance of the family as a social unit well above any measure of personal or erotic satisfaction and delighted in pointing out that the law warned people to exercise caution in contracting a lifelong bond. If they misjudged the case, the pain and penalty were theirs. "To the libertine, the egoist, the selfish, sensual seeker of personal and present enjoyment at whatever cost to others, the indissolubility of marriage is an obstacle, a restraint, a terror: and God forbid that it should ever cease to be!"8 That the indecisive, the deluded, the trusting, and the optimistic got caught in this trap as well was of little concern to Horace Greeley.

An alternate view, put forth most forcefully by Andrews and Owen, argued that family law should enable free choice and facilitate human 
relations in a way that approximated the laissez-faire model of economic regulation. Stanton sympathized with Owen and Andrews, assailing Greeley's view of law as Draconian and old fashioned. ${ }^{9}$ For all three, the emphasis on human will mandated a new view of law, one more enabling than coercive. They retained law within their social program, but as the servant and not the master: "Marriage itself, like the Sabbath, was made for man; not man for marriage." 10 A law that forced the continuation of an unhappy relation obstructed its purpose of securing happiness, and should be changed. "There is no absolute right or wrong about this matter of divorce; but that it may properly vary in its details at different stages of civilization." 11

Early nineteenth-century radicals and communitarians such as Robert Owen and Frances Wright had constructed the groundwork for such claims well before the meeting at Seneca Falls: however controversial and heretical their teachings remained, they had received a wide public airing. ${ }^{12}$ But although this radical tradition was at hand, most early feminists eschewed it. An emphasis on liberty, on the affective nature of the marriage bond, and on the need for divorce to ensure the happiness of the individual were strikingly absent from early feminist discourse. Perhaps with the exception of Stanton - a major exception they did not thrill to the "right" to dissolve the marriage bond and seek their romantic fortunes elsewhere. Rather, those who first approved of divorce saw it as self-defense, a measure of last resort to counter physical violence leveled at women by drunken and abusive husbands.

Before the Civil War, feminist arguments for divorce were not made in terms of an abstract right to individual liberty, but in more pragmatic terms, the most fundamental being the instinct for self-preservation. Story after story in women's papers such as the Lily and the Una, and in other works both fictional and factual, stressed the combined burdens of overwork and brutal treatment that could result in insanity or death for wives and mothers. Tales of marital violence were so frequent and widely known that one child-probably the son of reformers-grew up thinking of murder as a common contingency of marriage. ${ }^{13}$

Antebellum feminists most often invoked duties rather than rights as justification for divorce, particularly the mother's duty to children. Many women initially feared crossing the border into the land of absolute rights-bearers, and even Stanton - whose views were, as always, more radical-dwelt heavily on maternal obligation rather than rights in exhorting women to recognize the need for full and free divorce in cases of chronic inebriation. ${ }^{14}$ The physical safety of a drunkard's children was at issue as well as that of their mother; liberal feminists stressed her duty to remove them to a safer environment. 
The obligation to protect extended beyond living children to children unborn, and it became the basis of antebellum feminists' arguments for refusing husbands their "rights" in the marriage bed. Stanton relied heavily on what Linda Gordon has described as a folk wisdom of eugenics, preaching widely on the poor genetic harvest of unwilling unions. ${ }^{15}$ Exploiting the nineteenth-century passion for statistics, she calculated that of the nearly 1300 idiots in Massachusetts, between 1110 and 1200 had been born of alcoholic parents, and urged women to sever immediately conjugal relations with husbands who drank: "The unspeakable misery of looking a laughing idiot in the face and calling him 'my son' is known but to the mother's heart - the drunkard's wife." 16 Stanton's and Anthony's scientific Calvinism stressed the heritability of sin and preached that "[N]o woman should consent to be the wife of a drunkard because she may be the medium of stamping new forms of immortality on his gross, carnal nature. ..." At one New York Women's State Temperance Convention it was resolved that "it is a sin for any woman to consent to entail on innocent beings the curse and degradation that are the certain heritage of the Drunkard's offspring ..."17 Recognizing that abandoning the marriage bed was a painful and audacious step, Stanton counseled her readers that God in his benevolence never intended such a travesty of human happiness as a virtuous woman tied for life to a "loathsome, putrid carcass."18

The brutalized wife presented the most vivid and compelling case for divorce, but a higher-minded strain of thought ran through antebellum divorce arguments as well. One of the abolitionists' strongest arguments was that slavery illegitimately interposed human authority between the individual and God, thwarting that person's growth and development according to God's plan. The antebellum protest against the usurpation of God's authority took on new form in decrying marriage as subsuming the individuality of one person to the will of another. For liberal Protestants in full revolt against both the theology and political implications of Calvinist orthodoxy, the binding of the human will was both a crime and a sin, in marriage as elsewhere. Stanton and fellow feminist Antoinette Brown Blackwell adopted and embroidered this argument, using it to challenge the husband's authority. ${ }^{19}$ Stanton asked: "[H]ow can [woman] subscribe to a theology which makes her the conscious victim of another's will, forever subject to the triple bondage of man, priest, and the law... ? How can she endure our present marriage relations by which woman's life, health, and happiness are held so cheap that she herself feels that God has given her no charter of rights, no individuality of her own?"20

Obedience to God was a far easier principle for mainstream feminists 
to accept than one of individual happiness through severing the marital bond. The liberal Protestant notion of a newly benevolent God with designs for each individual's happiness provided Stanton with an argument in favor of divorce that was more acceptable to contemporaries in the 1850s. Stanton thus introduced into the divorce debateembedded in a theory of divine will and human duty-the ideas of individual happiness and the importance of personal growth, concepts that she would later develop into claims for personal autonomy.

\section{Marriage and Slavery in the Post-War Period}

In the post-Civil War period, the rhetoric of divorce changed dramatically as the language of rights replaced that of duty to God or children. For feminists, caught up in the great public debates of the post-war period, the wrongs of brutalized wives served as a catalyst for early consciousness of individual rights: "[it is] difficult to depict the woes of the drunkard's wife... without saying that her rights have been recklessly invaded, and wrongfully withheld." ${ }^{21}$ Earlier, divorce had been understood as an act of self-defense; now it became an issue of personal liberty. The idea of the right to one's body and to one's labor was a critical tenet of post-war political theory; liberal feminists adapted this "rights" definition to their own ends.

Slavery had ended, but slavery/freedom became the ruling paradigm through which liberal feminists conceived and developed their vision of rights within marriage. The analogy between marriage and slavery was natural and powerful, the conclusion inescapable: "Did the wives of all drunkards know that they have no master but God-that they are their own, and not the property of man - that woman is endowed with the same wants and capacities, and entitled to the same rights and privileges with him, they would not long wear the yoke of slavery. ..."22

Feminists' reliance on slavery imagery to express the plight of women grew naturally from the early ties with the abolitionist movement. The fledgling pre-Civil War woman's rights movement was ignited and fueled by women whose involvement in the anti-slavery movement had convinced them that arguments from natural rights and human dignity applied equally to women. Early feminists had labeled their own conditions as slavery, referring largely to the civil wrongs of coverture and disfranchisement. The direct analogy between slavery and marriage appeared less frequently: Despite criticisms of its legal trappings, the institution of marriage itself was accorded great deference. 
After the war, though, liberal feminists' use of slavery imagery took on a new directness, serving to describe the actual physical and emotional relations between husband and wife. Slavery imagery gained dominance and new meaning, and bondage became the metaphor of choice for pro-divorce feminists. Marriage itself had not become significantly more oppressive in those few years. Rather, the Emancipation Proclamation and the subsequent constitutional amendments offered a compelling new model for the articulation of grievances, grievances that in the slave's case had already been addressed with a suggestive array of constitutional rights and remedies. During the Civil War, antislavery ideology had developed into a political force invoking newly powerful models of government intervention to redress slavery's wrongs. In many respects, anti-slavery rhetoric was a more powerful political tool after the war precisely because of its new legal status. For antebellum reformers, slavery had held the status of a sin, a widespread corrupt practice that had offended notions of natural and divine law. By the late $1860 \mathrm{~s}$, enslavement had essentially become a crime, which human law outlawed and whose consequences human law sought to redress. The woman's rights movement's reliance on the mechanisms of human law grew reciprocally with the government's administration of equal protection standards through statutes and constitutional amendments. With feminist theory newly oriented toward legislative and policy goals, the franchise foremost among them, the slavery paradigm took on a new value as a language of political opposition. ${ }^{23}$

In gross terms, middle-class women who compared themselves to bondswomen may seem melodramatic and self-aggrandizing. But feminists felt themselves in both acute physical and spiritual bondage. The slavery/freedom dichotomy helped articulate common apprehensions of the illegitimacy of male and masterly authority, as well as women's genuine outrage at a marital servitude that many felt keenly was as degrading as actual bondage. In describing bad marriages, women spoke of being crushed, dwarfed, broken, crippled-a language of assaults on the body that resonated wildly in the immediate aftermath of the slavery contest. Stories abounded of wives who pictured themselves as "legalized slaves" to "masters" who meted out brutal treatment unchecked and unprovoked. An article in the Revolution entitled "The Slavery of Woman" offered a standard catalog of seductions, rapes, and assaults to which women had been subjected. One writer suggested, in the absence of anyone to raise a cry of "murder," that "we do it for ourselves, by stepping into the footprints of Garrison." 24

For those women who were fortunate enough to escape actual violence, codes and customs appeared to create manacles no less 
confining for being based on law, habit, and public sentiment. Even the ostensibly autonomous female body was encumbered by a scaffolding of hoops, buttons, and stays. One mother asked in defense of the Bloomer costume, "ought we, my child, to be enslaved by anything that cramps the freedom of the soul ...?"25 Stanton eloquently declared that "[O]ur evolution thus far is but a struggle to stretch ourselves while bound hand and foot, to fly with clipped wings, to breathe with an anesthetic held to mouth and nose... the oneness of man and woman [is] a oneness that makes woman a slave." ${ }^{26}$ Women wrote and read books with titles such as Hedged In, Forced Vows, and Fettered for Life, or, Lord and Master. ${ }^{27}$

Women's writing also made frequent literary use of the escape scene inspired by fugitives from the South. Diatribes against the laws of parental custody were laden with descriptions that drew on the Eliza story from Uncle Tom's Cabin, the slave mother escaping with her child, hounds baying at her heels. Such mothers, escaping their oppressive husbands, asked, "but he will follow me, will traduce me, and take my baby away from me, and the law won't give me my freedom, will it?"28

This sentimentalized presentation of marital enslavement and its consequences among all classes of society is portrayed vividly in Fettered for Life, or, Lord and Master, written in 1874 by the prominent suffragist and Stanton-sympathizer, Lillie Devereaux Blake. Despite its traditional format, the novel's moral was unconventional. The mortality rate for the novel's female characters is improbably high, and the author unsubtly conveys her message that "man-marriage," or the common model of male domination, takes a toll on women. Marital slavery plays itself out differently for each class, however, in a way that shows the growing recognition of class distinctions in feminist political analysis. Antebellum divorce and anti-marriage rhetoric had pictured all women as potential victims of a husband's drunken violence without acknowledging hurts or rights special to any group. But in Fettered for Life, women of different classes are at risk in different ways, and follow out particular patterns in their marriages.

The novel's working-class female characters-Biddy, Rhoda, Mrs. Blodgett - are especially vulnerable to physical abuse and have all been victimized by overt male brutality: seduced and abandoned like Rhoda, or like Biddy brought to death's door by an abusive spouse. Mrs. Blodgett, whose marriage to an underworld figure we follow throughout the narrative, remains a loving and subservient mate to a small-time criminal who finally kicks her to death in a drunken frenzy toward the end of the novel. 
By contrast, the genteel and middle-class Mrs. Moulder, overworked mother of three, suffers a more subtle oppression at the hands of a grumpy and domineering newspaper editor, who shreds her dreams of a more cultivated life with his mundane tyrannies rather than his fists. Violence here is displaced onto her pet canary, which Mr. Moulder kills with a thoughtless (but significant) blow while trying to return it to its cage. Mrs. Moulder, undone by the excitement, suffers a miscarriage and sinks into physical decline.

Harsh as these scenarios are, Blake saves the most vivid slave imagery for the case of Flora, wealthy daughter of a prominent businessman and best friend of the heroine. Clearly the gay, innocent, and talented Flora represents for Blake the most compelling and sympathetic case, one of "pure" enslavement without actual physical violence or demand. While relying heavily on images of male violence, middle-class feminists admitted that, in their understanding, women like themselves experienced less abuse than working-class women, for whom marital violence was often a way of life. ${ }^{29}$ While including domestic violence as an important part of their critique, many liberal feminists began to stress the suffering of the spirit above the suffering of the body as the true enslavement. The story of Flora illustrates how the slavery metaphor took on new meaning in their hands, as they focused more and more on the stifling of the will, talents, and independence as the most serious consequences of women's bondage.

Descriptions of the courtship of Flora and the worldly, wealthy roue who pursues her are shot through with the language of mastery. For months Flora resist LeRoy's overtures, fearing to become his "slave for life." Finally catching her unawares one night on the veranda, he forces a kiss on her, murmuring "my sweet trembling little prisoner, you are fairly caught. Give me your promise." In the face of his "irresistable will," "forceful eyes," "detaining hands," Flora "remained passive, unable to escape." After the kiss, "she was no longer free, no longer belonged to herself, she had received a master, and been compelled to submit to the symbol of his power....' I have passed under the yoke,' she thought, 'I am a slave.' " Thwarted in her attempt to escape, Flora continues to struggle weakly throughout the marriage ceremony, but "the iron clasp held her fast," and the vows were taken. ${ }^{30}$

Predictably, the marriage is an unhappy one: LeRoy forbids Flora to walk alone, see old friends, or follow her own pursuits. In defiance she takes up her writing again, and out of her anguish produces an extraordinary poem, which she secretly sends off for publication. LeRoy's anger at her independence precipitates a crisis and Flora's decline. On her deathbed she tells him that she can only be well again 
if he will lift his ban on the publication of her works; he refuses. ${ }^{31} \mathrm{Her}$ dying words to him are "Remember that women, as well as men, need an occupation for their energies, and marriage without love is worse than death.... There is light above my head-light and freedom!"32 Fettered for Life is emblematic of much liberal feminist thought, illustrating how the problem of wasted talents and the quest for professional opportunity - subjects with particularly middle-class appeal-became increasingly intertwined with the anti-slavery rhetoric of the marriage critique. ${ }^{33}$ The right to hold a job, to pursue a career or profession, came to be seen as a critical part of woman's emancipation.

\section{Marriage and Freedom of Contract}

Slavery's antithesis in nineteenth-century political discourse was freedom, and feminists' equation of marriage and slavery compelled their audiences to contemplate divorce through its obvious analogy, emancipation. The traditional marriage was undergoing its own Reconstruction. As Stanton declared, the growing number of divorces was not a sign of declining morals, but exactly the opposite: "Woman is in a transition period from slavery to freedom, and she will not accept the conditions of family life that she has heretofore meekly observed." ${ }^{34}$ According to the feminist agenda, what did freedom or emancipation entail for the married woman? In the view of a growing number of liberal feminists led by Stanton, its most important tenets were selfownership within marriage and a right to divorce if the marriage became degrading.

Linda Gordon and other historians of women have talked about "self-ownership" as a form of birth control ("voluntary motherhood") and as a radical assertion of sexual autonomy within marriage, both critical parts of nineteenth-century feminists' claims. ${ }^{35}$ The term itselfclearly predicated on slavery and coined to signify its literal oppositedrew on both abolitionist and free-love traditions. As Gordon has pointed out in her chapter on "Voluntary Motherhood," despite profound disagreement on other scores, a wide range of women activistsincluding free lovers, liberal feminists, and the more conservative Christian suffragists of the Woman's Christian Temperance Unionconcurred that married women were entitled to choose or refuse sex at will, according to their own desires and their wish to conceive. Thus, the "right to her own person" became a key feminist concept, language with little resonance in the earlier period. ${ }^{36}$ Stantonians claimed that 
next to self-ownership, which should "determine the future of the race," suffrage represented only a "simple question of political privilege." ${ }^{37}$

In a larger sense, Stanton and her sympathizers, in common with Victoria Woodhull, were attempting to restructure the idea of "right" to eliminate "obligation" altogether, broadly privileging the right to be free of obligation above the right to insist on the performance of a legal or contractual duty. They declared that "woman's degradation is in man's idea of his sexual rights." Placing woman's right to refuse above man's need for sexual relations, they denied that there was any male right at all, or any corresponding wifely duty. ${ }^{38}$ Drawing on the romantic anti-institutionalism of antebellum reform, liberal feminists transposed that language into an endorsement of voluntarism and radical personal autonomy. They decried the coercion of "marriage as a compulsory bond enforced by law and rendered perpetual by that means" and labeled every action and every relation that resulted from external coercion inherently corrupt. ${ }^{39}$

Woodhull and Claflin's Weekly took this road farther than even Stanton and Anthony did. An article with the suggestive title "Marriage Versus Freedom," whose author claimed Stanton's and Anthony's blessing on her views, declared that " $[F]$ reedom is the only right worth striving for . . . if, indeed, there are any other rights outside of and apart from personal freedom." She dismissed critics' objections that mutual obligations rendered complete personal freedom impossible: "[N]o person has any right to assume, to impose, such dependence on another as will make the exercise of that other's free will a source of unhappiness. Neither single nor mutual obligations should extend any further than the purest free will prompts; and then they are not obligations at all, but favors instead. ..."40

Although the writers for Woodhull and Claflin's Weekly went beyond most mainstream feminists in their emphasis on individual liberty, Stanton herself was in complete sympathy with their claims. She even publicly defended the position of mistress over that of wife on the grounds that it was a voluntary relationship and not legal bondage. ${ }^{41}$ This inherent privileging of a right to be free of obligations over any right to exact obligations impugned not just the marital bond, but an older structure that rested on reciprocal concepts of rights and duties: rights and obligations derived from status, by which the law described the roles and relationships of pairs like master-slave, husband-wife, parent-child. The rights that liberal feminists asserted-the right to vote, to own property, and to act as guardians of their own children worked to destroy some of the rights formerly vested in men, but put no one under any continuing obligation, and engaged no one in any 
reciprocal relationship. Liberal feminists repeatedly expressed their legal strategy as an attempt to lift laws that restrained and coerced, rather than as a way to obligate or coerce others. In the grand scheme, they sought " $[\mathrm{F}]$ reedom, freedom from all unnecessary entanglements and concessions, freedom from binding obligations involving impossibilities, freedom to repair mistakes, to express the manifoldness of our own natures, and to progress on, to advance to higher planes of development." ${ }^{42}$ Such radical autonomy left little room for ties. In their desire for freedom, in that binary understanding of slavery and freedom, which construed any customary or legal bond as making one unfree, liberal feminists predicated their claims on the assertion that "the laws of the individual sovereignty of women are more sacred than any human tie." 43

In this attempt to reconstruct the nature of obligation, liberal feminists moved naturally toward legal concepts. Seeking to recast the marriage relationship on more nearly equal terms, they groped for language that could express their vision in ways harmonious with mainstream thought. Contract was an obvious choice. The contractual ideal was pervasive in nineteenth-century society, so much so that to speak of feminists invoking contract as a "strategy" is misleading; it was the common coin of intellectual life, spreading far beyond its legal bounds to influence notions of reciprocity, obligation, and personal and business relations. Use of the slavery paradigm brought the issue of freedom of contract into play: In effect, the condition of slavery had less to do with disfranchisement than with a slave's more immediate inability to sever old work ties and form new ones and to bargain for a fair wagepowers that acquired almost mystical importance in the years around the Civil War. In addition to its more general civil status, then, "freedom" took on a narrower definition in the ability to make and break agreements at will. ${ }^{44}$ Contract provided women both with a theory of equal and reciprocal duties within an ongoing relation and also with a model for breaking that relation when the bargain went sour.

In addition to seeking justification for their interpretations of the marriage obligation in the law of contract, liberal feminists invoked God in their support as the first author of the dissoluble marriage contract. Stanton repeatedly pointed out, in her voluminous writings and far-flung speaking tours, that any legal bond that condemned one party to an unhappy and degraded existence violated God's own first plan for human happiness; the legal bond of marriage, then, must give way to God's most sacred decree, reinterpreted by his zealous female apostles in America as "what God had not joined together, let man 
put asunder." 45 According to Stanton, God's own laws now required of human beings that, rather than a sacramental or covenant theory of marriage relations, they subscribe to a theory of marital contract, with its inherent destructability. No bond in this new world could be irrevocably formed, for "any constitution, compact, or covenant between human beings, that failed to promote human happiness, could not ... be of any force or authority; and it would be not only a right, but a duty, to abolish it." 46

For Stanton, the concept of contract represented largely the deregulation of marriage, the noninterference of church and state in the private realm. It is true that feminists in the 1850 s were on the cusp of change: Initially repudiating human regulation as inimical to selfgovernment, women activists were beginning to see law as a tool that could be manipulated for their own ends. But it was the enabling rather than the enforcing power of law that appealed to feminists who sought to reform the marriage contract. Their view of the law of contract, although oversimplified, held that "all contracts, covenants, agreements, and partnerships are left wholly at the discretion of the parties." 47

Stanton did give some credence to the power of government to regulate the initial formation of contracts, including marriage. Citing the need for safeguards like minimum age, competence, and full disclosure, she encouraged legislators to remedy "the absence of form and dignity in the marriage contract which is unknown in any other civilized nation" with a strict set of prior conditions. ${ }^{48}$ But this list also reads as a set of contractual defenses, setting out grounds on which she thought divorce should be more easily granted or marriages annulled. Stanton pointed out that in other civil contracts, failure to comply with the conditions of entrance "vitiates the contract, and it is annulled by the mutual agreement of both parties. But in the marriage contract, which the state allows to be formed so thoughtlessly, ignorantly, irreverently, the parties have no control whatever, though ofttimes in its formation and continuance all laws of decency and common sense are at defiance. ..."49 Stanton sought tough entry and easy exit, but felt that stricter regulation of the creation of a marriage contract would cut down on failed marriages.

The notion of free contract served as a blueprint for remodeling the marriage relationship as well as for ending it. A part of the liberal project on marriage entailed demystifying it by applying to it the everyday terms of bargain and exchange, which governed arms-length agreements for services. Feminists used contractual analogies to describe faithful adherence to their marital terms, despite men's repeated violations of their own. Many men refused to perform their own obligations 
while insisting that women meet theirs, thus moving the agreement from the realm of contract into slavery. ${ }^{50}$ Several different writers for the Revolution in particular employed the language of employment relations and free labor to urge woman's more equal participation in "the marital partnership," lest the common imbalance "involve the bank of matrimony in hopeless bankruptcy." 51 The Revolution's boosting of free labor and free trade was not purchased with George Francis Train's money, but served as an integral part of a system of thought in which external compulsion was synonymous with imbalance or disfunction. ${ }^{52}$

The author of an unattributed four-part series of articles entitled "The Husband of Today" seems to have taken a leaf from the debate over the ownership of the craftsman's tools when she complains that the wife has "no legal right to that home which she is dutifully expected to beautify and make pleasant" because man has the "rightful ownership of all the goods and chattels of the family," rendering the wife little more than a slave. Like any other artisan, woman claimed more control of the workplace and of her "tools." When houses were designed by men, they misplaced the pantries and the sinks, little understanding the uses to which such objects were put: "The wife has, doubtless, good reason for the hot fire, the open draught, the large wash . . . she doubtless knows (her job) better than her husband," whose ignorant "sole management" only puts him in the category of "officious intermeddler." Sharply criticizing the profit motive, which made men unwilling to invest capital in the home, the author cites many women who "complained in the roundest terms, in the bitterest Saxon, that they were the drudges, the household slaves of money-getting husbands, who, provided they could lay by year after year money (one lady said $\$ 3,000$ ) of profits, are either indifferent to, or do not appreciate, the cares, sorrows, and overtoil of their wives ... with all the heavy claims of maternity, being made to work full up to the mark, like the man daylaborer... a dreary slavery in the free states." Women's rights included the right "to herself, to the use of all the powers and facilities God has given her, and the rights to the profits of her labor. ..."53

\section{Visions of the Family}

This vision of women's marital enslavement and emancipation through the recasting of marriage as a contract dissoluble at willlargely Stanton's vision - remained highly controversial within feminism itself, as well as attracting bitter criticism and attacks from 
outside. Opponents claimed that liberal reformers' programs threatened the nuclear family, and, in fact, these reformers did have a distinctive agenda with regard to the family's role and function. Within the larger debate, Greeley, as usual, staked out the orthodox position with his contention that the family's main function was, as the social agent of breeding, to provide for the training and education of children. This rationale bolstered his argument that the importance of lifelong marriage outweighed the happiness of the individual parties, because it best served the goals of stability and social order.

Liberal feminists emphatically rejected this utilitarian view, insisting that motherhood was simply one incident of womanhood, not its defining parameter. ${ }^{54}$ Reacting against attempts to shame women back into the home with stories of neglected children and motherly duty, they downgraded the maternal bond from the primary place it held in the nineteenth century to stand as only one of many other rights and obligations that made up female life, foremost among them the right to self. The contract model of marital relations could not easily be fitted to the parent-child relationship, but in rejecting the covenant model of permanent bonds, liberal feminists, with both intellectual and emotional conviction, sought to loosen their maternal ties by denying the aspect of demand or duty. Stanton's hypersensitivity to forced bonds led her to class all bodily obligations as feudal in nature; the law of perpetual physical union was an ancient horror from "those dark periods when marriage was held by the greatest doctors and priests of the church to be a work of the flesh only." 55

Such thoughts contributed to the accurate impression of many of the movement's critics that woman's rights, at least as Stanton envisioned them, would radically alter the marriage relationship. Indeed, the essence of that traditional bond would have been changed by the creed that held, "the moment any act expected of a person becomes compulsory, it becomes correspondingly irksome."56 In his writings, Greeley had emphasized the social bases of family relations. Stanton, Andrews, and Owen, by contrast, sought to establish marriage as an affective relationship based on a romantic love that was voluntary, ephemeral, spontaneous, and unresponsive to legal coercion. They looked to the "highest good of the individual. It is the inalienable right of all to be happy. It is the highest duty to seek those conditions in life, those surroundings, which may develop what is noblest and best." 57 Marriage was not a legal bond or social duty, but an affective relationship of mutual love and kindness, "intended by God for the greater freedom and happiness of both parties." " Downplaying its physical aspect, divorce reformers suggested that "It is not mere physical infidelity but 
that adultery of the heart which quenches conjugal love; thus destroying that which, far more justly than your cohabitation till death, may be regarded as "the essence of marriage." "59 By this standard, marriage "fulfills God's intentions so long as the domestic home is the abode of purity, of noble sentiment, of kindness...." By this standard, too, a marriage is broken not just by catastrophic upheaval, but when it becomes "the daily cause of grievous words and heartless deeds-of anger, strife, selfishness, cruelty, ruffianism." 60

Clearly, a marital relation that existed only through the rigor of the law and not the mutual love and ongoing consent of the parties was not conducive to the highest human development, and the furthering of happiness and human growth became the new standard by which social and political functions were judged. Utilitarianism combined with the developing creed of liberal Protestantism to produce a new rationale for institutions from the state down to the family. It was to accommodate this new vision of the family as constituted by the ongoing consent of the parties rather than by legal forms that Stanton sought to recast the marriage bond to eliminate any element of irrevocability or coercion from outside. She denied that marriage vows were anything but a voluntary, temporary mutual agreement for the benefit of both. Citing the "weakness and blindness" that led human beings to make poor decisions in the choice of business partners, legislators, teachers, and other public officers, she urged that the far graver matrimonial bond should be a "contract-no more perpetual than either or all of the former." ${ }^{\prime 1}$ By 1870 , Stanton declared that in the Protestant world the question was no longer whether marriage was a sacrament or a contract, but, as a contract, for what reasons it might be dissolved. ${ }^{62}$

Stanton envisioned the family as reforming along the lines of the republican state: it would consist of free and independent individuals, voluntarily contracting for a corporate existence during the pleasure of the parties, each protected in its own autonomy by inalienable individual rights. ${ }^{63}$ Many other feminists, though, felt the limitations inherent in the wholesale adoption of the personal liberty model of social change. The strict dichotomy between slavery and freedom worked to create a scheme of personal rights that could not accommodate the genuine physical and emotional dependencies of family relations. Stanton's rhetoric often pitted woman's right to herself against intimate demands pictured only as cloying and confining. For Stanton, "a single life of self-reliance, dignity, individual growth and development, is more sacred than a relation that subjects (woman) body and soul, to the will of another." ${ }^{64}$ 
Many feminists and reformers from across the spectrum resisted as pernicious Stanton's attempts to apply a commercial theory of contract to the marriage relation. Opponents of liberal divorce founded their arguments on the importance of the ideal, if not always the reality, of marriage as a permanent institution. For them, Stanton's use of contract theory provided a model of family relations that neither worked realistically to redress inequality, nor acknowledged the durability and permanence of parental or marital ties.

Religious precepts helped to shape these differing visions. Feminists like Antoinette Brown Blackwell resisted Stanton's contract theory, maintaining instead a covenantal view of marriage. Blackwell adopted a Christian ideal of marriage, not through an unthinking adherence to scriptural commands and injunctions, but through a belief in the doctrines of salvation, redemption, perfectionism, and atonement. Stanton offered human incompetence and frequent errors in choosing business partners, teachers, and other important contacts as evidence that the ability to dissolve such relations should always exist and in marriage, more so, since mistakes were frequent and costly. Blackwell too acknowledged problems within marriage, but her faith in marriage as a relation encompassed the "growth and assimilation of the parties" to each other and the smoothing out of differences over time that only the permanence of marriage would promote. The nature of moral life required that human beings maintain, if not the attraction and affection of their salad days, at least the "devotion to the good of another, and especially to the good of the sinful and guilty, [which] like all disinterestedness, must redound to the highest good of its author ... obedient to the highest laws of benevolence." ${ }^{65}$ A husband's irresponsibility provided the opportunity for a wifely redemptive intervention, for as a Christian she could "never enjoy peace or rest until [she had]... thus reclaimed him and brought him out of his sins ... as [she] would work to save [her] children, brothers, sister, and the whole human family." 66

Blackwell saw marriage not as a "tie" as Stanton had suggested, with the inbuilt possibility of untying, but as a "relation," which once formed can never be destroyed: one can "untie" but not unrelate ${ }^{67}$ For her, it was a critical, defining element of human nature that individuals could form a marriage relation through a single act of will that had permanent consequences. She frequently made analogies between marriage and biological ties, asking, "Can the mother ever destroy the relation which exists between herself and the child? Can the father annul the relation which exists between himself and the child? Then, can the father and mother annul the relation which exists between themselves, the parents 
of the child? It cannot be." ${ }^{\prime 68}$ Like Greeley, Blackwell believed that marriage by its nature continued for the lives of the spouses. Unlike him, she did not base her claim directly in social good, but in an imperative for the moral development of the individual. For her, the extraordinary characteristic of human love was the way in which it approximated divine love, in that it outlasted the span of human life.

By contrast, in Stanton's vision of romantic love, individual satisfaction described the nature of the bond. She derided the concept of Christian love in marriage, denying that husband and wife could ever act as saviors to each other. While her critics charged that love was a compound of "forebearance, patience, forgiveness, endurance," she eschewed these virtues, seeing marriage not as a process, a "soul perfecting itself through trial," but as a spontaneous emotional reaction. Stanton denied that love was an act of will, or that it could be deliberately prolonged by the parties once the fragile bloom was gone. ${ }^{69}$

Blackwell and Stanton differed fundamentally in their understanding of the connection generated in marriage. Stanton perceived marriage as a tie susceptible to dissolution at will. Blackwell described marriage as a relation whose very formation, although voluntary, entailed a permanent bond. For feminists such as Jane Croly, who questioned such "connective" definitions of marriage, the ties of circumstance and relation were inevitable, the definition of life itself, without which it would be impoverished.

We are tied from the moment we enter the world, and are probably the better and happier for it, though we may rebel against it. We are actual slaves to circumstances, which preceded our births, which enclosed us in a skin, which governed our height, our color, our shape, our strength or weakness, and over which we had not the least control. We are tied after birth to certain natural laws, which we very imperfectly understand, and of which we can only see the results. We are tied with cords woven by time itself to the habits and traditions which have preceded us; and more strongly still are we tied by our instincts and desires which, blind and unreasoning as they are, we are compelled to obey.... We see, then, there is very little of the freedom of which we boast so much in the matter. $^{70}$

Denying the theory of radical individual and bodily autonomy so important to Stanton, Croly saw interdependence: "as parts of one great body, we are all dependent upon and owe duties to each other." 11 What autonomy does an arm have, or a foot? For Croly, a body isolated was a body devalued; such a fiction flew in the face of the authentic conditions of life.

Stanton's refusal to acknowledge any social function of the family, 
or any legitimate church or state interest in regulating it, tended toward the complete privatization of the family, marking that area off as "personal" and impervious to regulation, for better or worse. ${ }^{72}$ The family became an isolated sphere, governed by a contractual ideal. Although Stanton's vision of the family did not go uncontested by her contemporaries, it is largely this view of family law that has prevailed in courts and legislatures today.

\section{Protectionism and Liberalism}

Despite the resistance to Stanton's stand on divorce both from within the movement and without, her influence proved far greater than a polling of her opponents might suggest. Divorce itself remained controversial, but pro-divorce arguments were a critical piece of the far broader liberal rights theory of which Stanton was a chief architect. Political savvy kept her from openly declaring herself a free lover, but a common store of ideas with a free love stamp became the basis of Stanton's political creed. ${ }^{73}$ Indeed, in one sense self-ownership-construed also as self-respect - came to replace more traditional "virtue" in the feminist canon as the qualification for citizenship, through the claim that all wise and virtuous government rested on the foundation of a citizenry with a strong sense of individual mastery. ${ }^{74}$ Without these, political rights were meaningless, for

if you go to a southern plantation and speak to a slave of his right to property, to the elective franchise, to a thorough education, his response will be a vacant stare ... the great idea of his right to himself, of his personal dignity, must first take possession of his soul, and then he will demand equality in everything. ... I repeat, the center and circumference of woman's rights is just what the slave's are. Personal freedom is the first right to be proclaimed, that does not and cannot belong to the relation of wife. ${ }^{75}$

The very concept of "right," then, was predicated on a world where those rights were to be exercised free of the legal and social restraints imposed by obligation to others. Liberal feminists sought to make the absolute right to oneself the basis for the exercise of rights within the state, and their rhetoric on personal rights and rights within the family became the basis of their model for the exercise of political rights. ${ }^{76}$ For Stanton, then, questions of family governance were measured by the same yardstick as questions about the role of the citizen in society and in the state.

In addition to applying the forms of contract to marriage, divorce 
reformers sought to tighten the correspondence between rights in the family and the civil realm by using constant analogies from other areas of law and public policy, which they brought to bear on the law of the family as well. To this end, Stanton, like Andrews and Owen, drew on analogies from liberal economic theory, free labor and free trade ideology, and the constitutional guarantees of freedom of conscience and separation of church and state to sketch in a new model of family law. Sensing a deep intellectual kinship, all three conflated such issues as free divorce, free love, free labor, free contract, and free trade. ${ }^{77}$ Stanton herself confirmed the connection between doctrines with the story of a man who refused Graham bread, "for he had noticed that if anybody began with bran bread, he was sure to end with infidelity"a somewhat eccentric formulation of a great progressive truth. ${ }^{78}$ Their opponent Horace Greeley had little trouble recognizing these reformers' organic approach. He lumped free traders, usurers, tax dodgers, and advocates of easy divorce together in one morally bankrupt category, claiming that "the free trade sophistry respecting marriage is on every libertine's tongue."' Andrews, for his part, commended Greeley, saying "You rightly refer free trade, freedom of the finances, freedom from state systems of religion and education, and freedom of the love relation, to one and the same principle, and that principle you recognize as the spirit of the age." ${ }^{80}$ Both sides, then, recognized that reformers were working to make the regulation of families of a piece with broader principles at work in areas of public and private commercial law. At heart, the problem in all areas was the same: to secure the removal of an external structure of laws to allow natural governing forces to assert themselves.

Although his proposals and his understanding of women's sexual subordination were radical for his day (and perhaps for ours), Andrews's political theory embodied strong liberal tendencies through his belief in the irresistable power of an underlying order and the need to eliminate all external regulation to allow that order to work unimpeded, a philosophy to which Stanton subscribed as well. A devoted disciple of Fourier, ("who really was about the most remarkable genius who has yet lived"), Andrews subscribed to Fourier's "grand discovery that Attraction, which Newton discovered to be the law and the regulation of the motions of material bodies, is equally the law and the Godintended regulation of the whole affectional and social sphere in human affairs." ${ }^{11}$ When the artificial restraints of law and custom were removed, the powerful force of Attraction would insure that human affairs were self-regulating, both in the economic and in the more important erotic world. Andrews saw the progress toward a fully self-regulating world 
as inevitable: "Freedom in love is the last attainment of the progressive civilized world. It is the culminating point toward which all other reforms tend. The system of restriction or arbitrary order in which the world was bound for ages is gradually dissolving." 82

Andrews and Stanton also analogized religious tolerance to liberal (non-regulatory) family laws, seeking to extend the established principles of freedom of conscience and of theological persuasion to cover unorthodox sexual relations as well. Andrews poked fun at one of his critics, suggesting that no "doubt ... he, too, is honest in his statement of the doctrine of religious freedom, and that he would, in practice, recognize my right to live with three women, if $m y$ conscience approved, as readily and heartily as he would contend for the rights to read the Protestant Bible at Florence." ${ }^{83}$ Andrews claimed for himself "no better right to determine what is moral or proper for you to DO than ... to determine what it is religious for you to BELIEVE," and likened such an attempt to the burnings at Smithfield. Any effort to regulate the moral lives of others through the mechanism of the state, Andrews suggested, would always end in the resort to such time-dishonored sanctions as "public odium, the prison, the gibbet, the hemlock, or the cross"- sanctions that may punish or suppress but never succeed in creating a truly harmonious order. ${ }^{84}$ Stanton heartily concurred that the rigid enforcement of the Christian ideal of lifelong monogamous marriage represented undue influence by church and state in the private lives of individuals.

Stanton's own repeated advocacy of free labor, free trade, and free currency shows that she extended her belief in deregulation to the economy; and that there was more than a superficial affinity between her views on marriage, her philosophy of government, and classic liberal notions of laissez-faire.$^{85}$ Indeed, reformers' efforts to meld those elements together shows a more complex face of liberalism than we usually see. Liberal theory is often portrayed as an amalgam of pessimism and human greed, but neither of these could account for the grip it took on American ideology. Stanton's liberalism was based firmly in a liberal Protestant creed that celebrated the innate goodness of human nature and its ability to find its own right course once external regulation was lifted. Despite her anticlericalism, Stanton was a child of the Second Great Awakening and subscribed to its tenets on the efficacy of human will. ${ }^{86}$ The Christian perfectionism of the antebellum period-perfection of the soul-translated for many in the post-war period into a perfection of the life and of the work-human happiness. Although their interests were not the same, liberal reformers made common cause with business interests on the best method of 
securing change of any sort: deregulation. Nineteenth-century liberalism, then, was not a single strand, but a complex weave of economic, political, and religious philosophies, and it was much the stronger for it.

The issue of protection had also been at stake in the wrangling that went on among Andrews, Owen, and Greeley in the decade before the Civil War. As an anarchist, Andrews was a strong proponent of selfgovernment or self-sovereignty - the idea that any authority exercised by one human being over another interposed itself illegitimately between the individual and God's governance - a belief shared by abolitionists and feminists as well. In the context of free love, this concept expressed itself most radically in terms of the freeing of the body from any obligations imposed from without. A chief architect of the free lovers' creed of the absolute right of the individual to bodily mastery and integrity, that independence became for Andrews the single most important measure of social health, while the physical subjugation of women in American society was a prime indicator of its diseased state. Like Stanton, he saw bodily obligations as evidence of an ancient serfdom repugnant to enlightened minds. Andrews saw himself as a revolutionary fighting against "the defenders of slavery, and the fastidious aristocratic classes everywhere," as well as against all vestiges of the feudal structure of hierarchy, tenures, and paternalism, which placed, protected, and imprisoned the individual.

Stanton's composite writings and pronouncements tended toward the disaggregation of the family as well, an outcome she found personally, socially, and politically desirable. Her philosophy of marriage emphasized the aspect of individual development, and the severing of obligatory ties and dependencies contributed to this. ${ }^{87}$ Socially as well, Stanton was convinced that only the removal of all restriction on women-domestic, civil, and physical-could bring them into a position of full equality. Politically, she classed the patriarchal family with "despotic governments (and) infallible churches.... Every new step in civilization tends to individual awareness, dignity, responsibility, alike in the church, the state, and the home." ${ }^{88}$ Clearly, the democratic reorganization of the family required that each individual be accorded full status and rights: Stanton denied that the "representative" theory of the family as a "unit" was acceptable. Government should deal with individuals, not with families, or with certain of its members as representatives of others. ${ }^{89}$

Inherent in the push for the disaggregation of the family was the recognition that, like slavery or the harem, the protection offered by family membership was often at the price of liberty. For slaves, being 
" "a part of the family" " had "protected" them from the onus of taxation, as well as denying them a civil voice: leaving the "family" changed both..$^{90}$ Any physical obligation that owed its existence to a code or rule was similarly discredited: just as Horace Greeley denounced "the free trade sophistry respecting marriage," the liberal feminists equated the safety of marriage with the harem, paternalism, and slavery, claiming "protection is the leech that preys upon the heart of liberty." "Protectors" take on a sarcastic significance in Stanton's work as those who rape and seduce women..$^{91}$

In fact, discussions of the marriage question both within and without organized feminism also centered on another set of issues-economic protection and the consequences of easy divorce for wives and mothers. In 1860, Stanton's and Blackwell's optimistic beliefs in the potential for the liberated and energetic woman to achieve economic parity allowed both to ignore the problem of dependence. ${ }^{92} \mathrm{~A}$ decade later, some feminists were more skeptical. Stanton's brash and public advocacy of divorce was an irritant that contributed to the estrangement of the New York and Boston feminist groups. Although Lucy Stone and Henry B. Blackwell almost certainly agreed with Stanton in private, they feared that her public stance would taint the quest for the ballot and lose the suffrage movement crucial support. They steadfastly refused to acknowledge the link between civil and domestic inequality, naively arguing that, once the lack of political rights for women had been redressed, relations between the sexes would right themselves as a natural consequence.

At the same time, writers for the Woman's Journal, the paper of the American Woman Suffrage Association (AWSA), had another complaint to make: They found Stanton's rhetoric naive and disingenuous in its assumption that free divorce would primarily benefit women. How many mothers, under the circumstances, could afford to sweep grandly out and set up housekeeping on their own? Stone and her followers intimated that "freedom" for a divorced mother of six should be known as its other names, immiseration and abandonment. For the suffragists of the AWSA, divorce was at best an unfortunate necessity in cases of chronic spousal abuse, but free divorce in Stanton's terms represented "practically, freedom of unworthy men to leave their wives and children to starve, while it could not give similar freedom to mothers to leave their children." ${ }^{93}$ Neither wing of the suffrage movement showed any abiding sensitivity to the problems of working class women, the AWSA less than Stanton's group. The Boston contingent, though, grasped that the "right" of divorce must be seen in light of prevailing economic conditions, where "a wife with children, who has lost the help of her 
husband, has undertaken a contest with fortune against heavy odds."94 The imperative of self-sovereignty, then, left little room for financial, physical, or emotional obligation of any kind. As Andrews had earlier announced, "The great lesson for the world is that human beings do not need to be taken care of. What they do need is such conditions of justice and friendly cooperation that they can take care of themselves." Stanton concurred that the dangers of protectionism far outweighed the problems of poverty. ${ }^{95}$

\section{Conclusion}

The adoption of the slavery metaphor for marriage - with its reflexive counter, freedom - had weighty consequences for the development of feminist thought in America. It gave feminists an immediate and powerful concept and a language of personal independence that resonated in the dominant culture. It also carried a transformative vision of equality. There were several feminist traditions in the nineteenth century, but it is this vision of liberation that the woman's movement of the mid-twentieth century has drawn on for support and sustenance. The ideal of personal freedom has proven durable as a spark to political action that addresses women's deepest concerns. More than a century later, well after political "equality" was established by the Nineteenth Amendment, the idea of escape from bondage fueled a women's movement that has changed the shape of American social life.

At the same time, the process of defining rights, occurring both within feminism and in the larger political culture, through the paradigm of slavery and freedom, transformed their meaning. In Stanton's liberal view, shaped by her post-Civil War contractual view of marriage, rights originated in the private sphere, not within the context of social or public life. The Revolution argued that the assertion of self-ownership for women must become "the paramount and controlling influence of her life, for individual freedom of choice is the cornerstone of individual responsibility, and all virtue and wise government must rest on this foundation." Only then, when responsible alone to God and herself, she shall possess the right to life and liberty, she will occupy a position in which she will logically be capable of becoming a Beneficent Power." 96 Departing from the antebellum formulaton that rights were both the offspring and the agent of performing duties, Stanton insisted that rights were paramount and antecedent to duties. The earlier notion that the perfection of individual rights was the only means of protecting the rights of the community gave way to language that pitted the 
individual against the community: Stanton concluded that "the best interests of a community can never require the sacrifice of one innocent being, of one sacred right." 97

The elevation of the individual right to a position of absolute authority created a philosophical framework in which it was easiest to recognize the negative right, the right to be free from something, where the balancing of rights through the recognition of binding claims by one person on another was made, if not impossible, at least conceptually dubious. Sarah Norton, a contributor to Woodhull and Claflin's Weekly, spoke for much of nineteenth-century feminism - indeed, much of nineteenth-century liberalism - when she asked, "wherein, then consists the value of a right that cannot be appropriated at the option of the individual possessing it? or how much of the value or usefulness remains, if it is to be subject to the control of some greater right?"98

Liberal feminists, pushing the argument that "we do not live by bread alone," were compelled to downgrade the importance of financial "security" in marriage, in order to establish it as an affective relationship between equals. ${ }^{99}$ This emphasis hindered meaningful discussion among Stantonians about another set of issues-economic protection and the consequences of easy divorce for wives and mothers. Ultimately, despite her quick sympathy with the oppressed of all sorts, Stanton's preoccupation with individual freedom prevented her from developing a coherent class-based theory that invoked systematic legal or institutional remedies to women's position in marriage. Stanton, throughout her life, maintained a belief in the primacy of change at the personal level. She judged civil perfection to be the result of the perfection of individuals, a belief that after the war was translated into a defense of individual rights. Stanton suggested that women's rise should follow the projected path of the slave: "end all this talk of class legislation, bury the Negro in the citizen, and claim the suffrage for all men and women." She rejected any argument based on the "rights of races," and accepted as the only rationale for reform the slave's "manhood; his individual, inalienable right to freedom and equality; and thus ... woman's case today." 100

Such an idealistic response to the practical problems of racism and sexism has left a mixed legacy for twentieth-century feminists. Ultimately, Stanton's theories, by undermining the bonds between individuals within the family and by placing the source of rights in this deregulated private sphere, may have made it more difficult to assert group rights in the larger social setting. The contractual theory of liberal individualism has never proven a satisfactory mediator of family relations, nor has the extension of that theory into the civil sphere 
created a basis for the assumption by the state of family obligationsday care, medical care for children, parental leave-that could genuinely change the lives of working women.

\section{NOTES}

This paper was first presented at the University of Wisconsin in 1986, at a seminar on the history of family law, which was sponsored by the National Endowment for the Humanities. I would like to thank the members of that seminar, especially Martha Fineman, Dirk Hartog, Amy Dru Stanley, and Carol Weisbrod, for their comments. Suggestions from Christine Stansell, Daniel T. Rogers, and Marylynn Salmon and the gentle, ruthless editing skills of Andrea Rusnock and Catherine Peyroux helped enormously as well.

1. Report of the Woman's Rights Convention Held at Seneca Falls, New York, July 19 and 20, 1848 (1848; reprint New York, 1969), 6.

2. William O'Neill, Divorce in the Progressive Era (New Haven, 1967).

3. Stanton's writings on divorce are not collected in any one place. The major sources, which contain most of her ideas on the subject, are in Elizabeth Cady Stanton, Susan B. Anthony, and Matilda Joslyn Gage, eds., History of Woman Suffrage (New York, 1881), 1: 716-22, 738-42, 860-61; "Address of Elizabeth Cady Stanton on the Divorce Bill before the Judiciary Committee of the New York Senate ... Feb. 8, 1861" (Albany, 1861); "Mrs. Elizabeth Cady Stanton's Address at the Decade Meeting on Marriage and Divorce," in A History of the National Woman's Rights Movement for Twenty Years, ed. Paulina Wright Davis (New York, 1871); and "Marriage and Divorce," unpublished manuscript, Stanton Papers, Douglass College Library, Rutgers University. Ellen DuBois includes relevant selections from Stanton's work in Elizabeth Cady Stanton, Susan B. Anthony: Correspondence, Writings, Speeches (New York, 1981).

4. Ellen DuBois has explicated the transformative nature of Stanton's rights theory, primarily in Feminism and Suffrage: The Emergence of an Independent Woman's Movement in America, 1848-1869 (Ithaca, N.Y., 1978); and Dubois, Elizabeth Cady Stanton.

5. The contest was advertised repeatedly in the Lily starting in January of 1853 . The first entry appeared in the Lily ca. Sept. 1853 (date illegible); others in the issues for Jan.-March 1854 (vol. 6 nos. 1-3).

6. Lily 4, no. 10 (August 1852): 69.

7. The debates between Greeley, Andrews, and Henry James, Sr., appeared in the Tribune in 1852 and 1853 . They were reissued with an introduction by Charles Shively in Love, Marriage, and Divorce, and the Sovereignty of the Individual (Weston, Mass., 1975). James's arguments are rather less lucid than Andrews's or Greeley's, and I have omitted them. Greeley's 1860 exchange with Robert Dale Owen was reprinted in the back of Greeley's autobiography Recollections of a Busy Life (1868; reprint, New York, 1970) as "Marriage and Divorce."

8. Greeley, "Marriage and Divorce," 606.

9. Stanton addressed Greeley specifically about the matter; see Stanton, Anthony, and Gage, History of Woman Suffrage 1:738-42.

10. Greeley, "Marriage and Divorce," 577.

11. Ibid., 584. 
12. Sidney Ditzion, Marriage, Morals, and Sex in America: A History of Ideas (New York, 1953), especially chapter 3. See also Barbara Taylor, Eve and the New Jerusalem: Socialism and Feminism in the Nineteenth Century (New York, 1983). Robert Owen, the founder of the community at New Harmony, Indiana, lectured and published tracts in favor of cheap and easy divorce in the 1830s and 1840s. Fanny Wright's community, Nashoba, was notorious for its loose sexual practices and the liberal terms of its marital arrangements.

13. Elizabeth Oakes Smith, The Sanctity of Marriage (Syracuse, 1852), 7-8.

14. Recent historical work has stressed the pragmatic nature of much of the midcentury reform of marital women's property laws and rules of custody, not as extensions of absolute rights but as piecemeal efforts by legislatures to protect women in carrying out what were in fact rapidly growing roles in household management and domestic finance. See, for example, Suzanne Lebsock, The Free Women of Petersburg: Status and Culture in a Southern Town, 1784-1860 (New York, 1984); Richard Chused, "Married Women's Property Law, 1800-1850," Georgetown Law Journal 71 (1983): 1359-1425; and Michael Grossberg, Governing the Hearth: Law and the Family in Nineteenth-Century America (Chapel Hill, 1985).

15. Linda Gordon, Woman's Body, Woman's Right: A Social History of Birth Control in America (New York, 1976), especially chap. 6, "Social Purity and Eugenics."

16. Lily 2, no. 4 (April 1850): 31.

17. Ibid. 4 , no. 7 (July 1852): 57-58.

18. Ibid., no. 10 (August 1852): 69.

19. Stanton and Blackwell engaged in a protracted debate on divorce at the national woman's rights meeting in 1860. See Stanton, Anthony, and Gage, History of Woman Suffrage 1:716-735.

20. Letter of Nov. 24, 1856, Stanton Papers, Douglass College Library, Rutgers University.

21. Lily 4, no. 3 (March 1852): 22.

22. Ibid., no. 2 (Feb. 1852): 13.

23. The growth of women's political culture is discussed by Paula Baker in "The Domestication of Politics: Women and American Political Society, 1780-1920," American Historical Review 89, no. 3 (June, 1984): 620-47. See also Lori D. Ginzberg, “" Moral Suasion is Moral Balderdash': Women, Politics, and Social Activism in the 1850s," Journal of American History 73, no. 3 (December 1986): 601-22.

24. Revolution 1, no. 14 (April 9, 1868): 216-17.

25. Ibid., no. 16 (April 23, 1868): 244-45.

26. Stanton, letter to Isabella Beecher Hooker, April 12, 1871, Douglass College Library, Rutgers University. Stanton claimed great success for her marriage lectures on the circuit.

27. Hedged In is by E. S. Phelps; the other two are by Lillie Devereaux Blake, published in 1870 and 1874 , respectively.

28. Woodhull and Claflin's Weekly, Oct. 29, 1870, p. 10.

29. "The Slave Women of America," Revolution 6, no. 14 (October 6, 1870): 216.

30. Blake, Fettered for Life, 73, 128, 129, 264.

31. This is the first documented instance of the adage, "publish or perish."

32. Blake, Fettered for Life, 351. Another of Blake's publications contains a similar story of the atrophied and wasted talents of a beautiful young girl, "now in an alien grave, dead by her own hand.” Lillie Deveraux Blake, Woman's Place Today (1890), 64.

33. Revolution 1, no. 18 (May 7, 1868): 278-79. 
34. Quoted in Ellen DuBois, "The Limitations of Sisterhood: Elizabeth Cady Stanton and Division in the American Suffrage Movement, 1875-1902," in Women and the Structure of Society, ed. Barbara J. Harris and JoAnn K. McNamara (Durham, N.C., 1984), 166-67.

35. Gordon, Woman's Body, Woman's Right, chap. 6. See also Daniel Scott Smith, "Family Limitation, Sexual Control, and Domestic Feminism in Victorian America," Feminist Studies 1, nos. 3/4 (1973): 40-57, reprinted in Clio's Consciousness Raised: New Perspectives on the History of Women, ed. Mary S. Hartman and Lois W. Banner (New York, 1974); and William Leach, True Love and Perfect Union: The Feminist Reform of Sex and Society (New York, 1980), especially chap. 4, "Sexual Ownership and the Rationalization of Sexual Desire."

36. Gordon, Woman's Body, Woman's Right, 95-97. Despite their common belief in such a right, mainstream feminists disapproved of the free love movement. Stanton's views were complicated: She agreed with Victoria Woodhull's basic philosophy that women's sexual oppression must be ended before civil rights for women would be meaningful. The free love movement provided critical support for her insistence that the right of self-ownership was central, not peripheral, to the cause of women. On occasion she openly endorsed the philosophy: see Ellen C. DuBois, "On Labor and Free Love: Two Unpublished Speeches of Elizabeth Cady Stanton," Signs 1, no. 1 (1975): 257-68. At the same time, she did not go nearly as far as the free lover Victoria Woodhull in urging the positive value of erotic pleasure governed only by the lover's immediate inclination; she herself maintained a strong belief in monogamy.

37. Woodhull and Claflin's Weekly, Sept. 10, 1870, p. 4.

38. Theodore Stanton and Harriot Stanton Blatch, eds., Elizabeth Cady Stanton (New York, 1922), 2:82. See also John Cowan, Science of a New Life (1874; reprint New York, 1970).

39. DuBois, "On Labor and Free Love," 265.

40. Sarah Norton, Woodhull and Claflin's Weekly, Oct. 22, 1870, p. 7.

41. Revolution 2, no. 15 (October 15, 1868): 233.

42. DuBois, "On Labor and Free Love," 266.

43. Revolution 5, no. 20 (May 19, 1870): 309. See also Stanton and Blatch, Elizabeth Cady Stanton 2:82.

44. On the place of contract in American legal and social life, see J. Willard Hurst, Law and the Conditions of Freedom in the Nineteenth-Century United States (Madison, Wis., 1956); Morton Horwitz, The Transformation of American Law (Cambridge, Mass., 1977), 160-210; Grossberg, Governing the Hearth, 20, 23-24; and Amy Dru Stanley, "Conjugal Bonds and Wage Labor: Rights of Contract in the Age of Emancipation," Journal of American History 75 no. 2 (September 1988): 471-500.

45. Revolution 3, no. 23 (June 10, 1869): 362. See also the resolutions offered at the 1860 National Woman's Rights Convention, reprinted in Stanton, Anthony, and Gage, History of Woman Suffrage 1:716-17.

46. Stanton, Anthony, and Gage, History of Woman Suffrage 1:716.

47. Elizabeth Cady Stanton, "Address ... on the Divorce Bill Before the Judiciary Committee," 10. See also Revolution 2, no. 17 (October 29, 1868): 264.

48. Davis, History of the National Woman's Rights Movement, 68; Stanton, Anthony, and Gage, History of Woman Suffrage 1:718; Revolution 2, no. 16 (October 22, 1868): 249-50.

49. Davis, History of the National Woman's Rights Movement, 68.

50. Revolution 1, no. 24 (June 18, 1868): 381.

51. Ibid. 5, no. 6 (February 10, 1870): 94. 
52. Stanton, in an article entitled "Free Trade," denied that since Train dissociated himself from the Revolution it had gone over to "Greeley and the Protectionists." "Commerce is ever the pioneer of civilization and Christianity, and every barrier in the way of exports and imports blocks the wheels of progress and retards the moral and intellectual development of all the races of man." Ibid. 3, no. 15 (April 15, 1869): 233.

53. Revolution, part 1, vol. 3, no. 18 (May 8, 1869): 275; ibid., part 2, vol. 3, no. 20 (May 20, 1869): 310; ibid., part 3, vol. 3, no. 25 (June 24, 1869): 386; ibid., part 4, vol. 4, no. 1 (July 8, 1869): 3 .

54. For example, Revolution 1, no. 15 (April 16, 1868): 229. Stanton's own attitude toward domesticity was ambivalent. The mother of a large family, she styled herself a great matriarch and roamed public conveyances giving young mothers unsolicited advice from the idiosyncratic and advanced maternal theories of which she was so proud. As her family grew, though, she acknowledged a growing weariness at household tasks that confined her, and it was in part resentment at the physical demands of women's lives which fueled her own quest for autonomy. See in general Elisabeth Griffith, In Her Own Right: The Life of Elizabeth Cady Stanton (New York, 1984).

55. Stanton, Anthony, and Gage, History of Woman Suffrage 1:716-17.

56. Woodhull and Claflin's Weekly, Nov. 5, 1870, p. 6.

57. Stanton, Anthony, and Gage, History of Woman Suffrage 1:717.

58. Ibid., 860 .

59. Greeley, "Marriage and Divorce," 585.

60. Ibid., 577.

61. Stanton, Anthony, and Gage, History of Woman Suffrage 1:717-18.

62. Davis, History of the National Woman's Rights Movement, 64-65.

63. Stanton, Anthony, and Gage, History of Woman Suffrage 2:18-19.

64. Revolution 5, no. 9 (March 3, 1870): 136.

65. Stanton, Anthony, and Gage, History of Woman Suffrage 1:723.

66. Ibid., 726.

67. Ibid., 724 .

68. Ibid.

69. See Leach, True Love, 10-11.

70. Jane Croly, For Better of Worse: A Book for Some Men and All Women (Boston, 1875), 4.

71. Ibid., 221.

72. In this sense, Stanton's family design looked very much like the privatized family Christopher Lasch describes in Haven in a Heartless World: The Family Besieged (New York, 1977).

73. DuBois suggests this in "On Labor and Free Love."

74. Revolution 5, no. 10 (March 10, 1870): 147.

75. Letter from Stanton to Susan B. Anthony, Nov. 24, 1856, Stanton papers, Douglass College Library, Rutgers University.

76. Matilda Joslyn Gage, one of Stanton's strongest allies, restated this position at the NWSA convention in 1876, saying "without control of one's person, the opportunities of the world, which are the only means of development, cannot be used." Quoted in Leach, True Love, 81.

77. Stanton, Anthony, Gage, History of Woman Suffrage 2:19. Theodore Dwight Woolsey, foe of divorce, parodied these connection as "free rum, free Sundays, free suffrage, and free divorce." Woman's Journal, Nov. 26, 1870, p. 372.

78. Stanton, "Free Love," 268. 
